\title{
Pengembangan Lembar Kerja Peserta Didik (LKPD) pada Materi Teks Fabel Berbasis Saintifik untuk Siswa SMP Kelas VIII
}

\author{
Yeni Ernawati \\ Universitas Bina Darma Palembang \\ Corresponding email: yeni.ernawati@binadarma.ac.id
}

\begin{abstract}
The purpose of this study was to describe the needs of students and teachers for learning to write scientific-based fable text, produce teaching materials on Student Worksheet (LKPD) on scientific-based Fable Text material, and describe the results of expert validation of the developed LKPD. This research is a development study using a modification of the development model of Dick, Carey, and Carey and Jolly \& Bolitho. The subjects of this study were students of class VIII and Indonesian Language Teachers. Data collection techniques are done using a questionnaire and documentation. The feasibility of the developed teaching material is known from the results of validation by three experts on the 4 components of teaching material, namely the component of material eligibility, language component, presentation component and graphic. Based on the results of expert validation, LKPD on the fable text material developed is categorized as good or suitable to be used as a textbook companion teaching material. In the content / material component, LKPD outlines one Basic Competency (KD) in each activity. Each activity is in accordance with the steps of the scientific approach that is equipped with worksheets and assessment rubrics so as to facilitate students and teachers in the learning and assessment process. In the language component, LKPD uses simple and effective language, and is equipped with a glossary to make it easier for students to understand new vocabulary. In the presentation and graphic components, LKPD uses larger types and font sizes, and attractive designs with illustrations of colored images.
\end{abstract}

Keywords: Development of LKPD, Fable Story Text Material, Scientific Approach

\begin{abstract}
Abstrak
Tujuan penelitian ini adalah untuk mendeskripsikan kebutuhan peserta didik dan guru terhadap pembelajaran menulis teks fabel berbasis saintifik, menghasilkan bahan ajar Lembar Kerja Peserta Didik (LKPD) pada materi Teks Fabel berbasis saintifik, dan mendeskripsikan hasil validasi ahli terhadap LKPD yang dikembangkan. Penelitian ini merupakan penelitian pengembangan dengan menggunakan modifikasi model pengembangan Dick, Carey, and Carey dan Jolly \& Bolitho. Subjek penelitian ini adalah peserta didik kelas VIII dan Guru Bahasa Indonesia. Teknik pengumpulan data dilakukan menggunakan angket dan dokumentasi. Kelayakan bahan ajar yang dikembangkan diketahui dari hasil validasi oleh tiga pakar pada 4 komponen bahan ajar, yaitu komponen kelayakan isi/materi, komponen bahasa, komponen penyajian dan kegrafikaan.
\end{abstract}


Berdasarkan hasil validasi ahli, LKPD pada materi teks fabel yang dikembangkan dikategorikan baik atau layak untuk digunakan sebagai bahan ajar pendamping buku teks. Pada komponen isi/materi, LKPD menguraikan satu Kompetensi Dasar (KD) dalam setiap kegiatan. Setiap kegiatan sesuai dengan langkah pendekatan saintifik yang dilengkapi dengan lembar kerja dan rubrik penilaian sehingga memudahkan peserta didik dan guru dalam proses pembelajaran dan penilaian. Pada komponen bahasa, LKPD menggunakan bahasa yang sederhana dan efektif, serta dilengkapi glosarium untuk memudahkan peserta didik memahami kosakata baru. Pada komponen penyajian dan kegrafisan, LKPD menggunakan jenis dan ukuran huruf yang lebih besar, dan desain yang menarik dengan ilustrasi gambar-gambar berwarna.

Kata Kunci: Pengembangan LKPD, Materi Teks Cerita Fabel, Pendekatan Saintifik

\section{PENDAHULUAN}

Dalam kegiatan pembelajaran, salah satu komponen yang turut menentukan kualitas pembelajaran dan keberhasilan tercapainya tujuan pembelajaran adalah bahan ajar (Nugroho \& Fitri, 2018:117; Marianita \& Artati, 2018:175). Bahan ajar yang disusun guru harus mampu memberikan kegiatan peserta didik yang bersifat kreatif, kolaboratif, kerja sama, dan berpikir kritis (Noermanzah \& Friantary, 2019:6631). Banyak jenis dan bentuk bahan ajar yang digunakan dalam kegiatan pembelajaran, salah satunya adalah buku teks pelajaran. Buku teks pelajaran merupakan salah satu bahan ajar yang digunakan oleh guru dan peserta didik. Banyak penyusun dan penerbit buku yang menyediakan buku teks pelajaran, tetapi penyampaian materi pada buku teks tersebut bersifat umum. Hal tersebut terkadang tidak sesuai dengan kebutuhan peserta didik pada setiap sekolah yang berbeda. Ketidaksesuaian tersebut dapat diatasi dengan cara menggunakan bahan ajar tambahan yang mampu mendukung kegiatan penyampaian materi pembelajaran sesuai dengan kebutuhan peserta didik. Guru dapat menyusun atau mengembangkan bahan ajar sederhana untuk peserta didik.

Proses penyusunan bahan ajar harus sesuai dengan kurikulum yang sedang berlaku di sekolah. Sekarang, sekolah-sekolah baik SMP maupun SMA sudah menerapkan Kurikulum 2013. Dalam K-13, materi pembelajaran bahasa Indonesia berbasis teks. Salah satu teks sastra yang menjadi tujuan pembelajaran pada Kurikulum 2013 adalah menulis teks cerita fabel. Fabel adalah cerita didaktik yang yang menceritakan kehidupan hewan yang berperilaku menyerupai manusia yang mengandung nilai moral dalam kisahnya (Sarumpaet, 2010:22). Teks cerita fabel disebut juga cerita moral karena di dalam cerita terdapat nilai-nilai moral. Dengan mempelajari teks cerita fable sama seperti karya sastra lainnya, peserta didik diharapkan dapat memahami dan menerapkan nilai-nilai moral yang tersirat maupun tersurat pada teks sehingga memberikan pengaruh pembentukan karakter mereka (Nugroho, 2018). Nilai-nilai moral yang terdapat dalam teks cerita fabel, baik secara tersurat maupun tersirat diharapkan dapat diserap dengan baik oleh peserta didik, sehingga memberikan kontribusi dalam pembentukan karakter mereka.

Selain buku ajar utama, guru juga dapat menggunakan bahan ajar komplementer untuk memperkaya sumber belajar peserta didik. Salah satu bahan ajar komplementer yang dapat digunakan adalah LKPD. Lembar Kerja Peserta Didik (LKPD) adalah nama lain dari Lembar Kerja Siswa. Hal tersebut sejalan dengan perubahan kurikulum KTSP ke Kurikulum K-13 yang menyebut siswa menjadi 
peserta didik. Lembar Kerja Peserta Didik (LKPD) merupakan salah satu bahan ajar cetak berupa lembaran-lembaran berisi materi pembelajaran dan tugas-tugas atau kegiatan pembelajaran yang mengacu pada suatu kompetensi dasar dan disusun sedemikian rupa, yang juga dimaksudkan untuk membantu siswa belajar secara terarah, sistematis, dan mandiri. Oleh karena itu, peneliti mengembangkan bahan ajar komplementer LKPD.

LKPD dapat disusun berdasarkan KD tertentu, sebagaimana yang disampaikan oleh Suryaman (2012) yang mengemukakan bahwa dalam mata pelajaran bahasa Indonesia, LKPD dapat dikembangkan per-KD. Peneliti memfokuskan pengembangan materi bahan ajar pada kompetensi pengetahuan, yaitu memahami teks cerita moral/fabel dan kompetensi keterampilan, menyusun teks cerita moral/fabel. Kedua kompetensi tersebut diimplementasikan dalam dua kegiatan pembelajaran. Pertama, memahami teks cerita fabel, yang terdiri pemodelan teks cerita fabel, tugas kelompok dan tugas individu dalam mengidentifikasi struktur teks, dan kaidah kebahasaan. Kedua, menulis teks cerita fabel, yang terdiri pemodelan teks cerita fabel, tugas kelompok, dan tugas individu dalam menulis teks cerita fabel.

LKPD teks cerita fabel dikembangkan sesuai dengan kebutuhan peserta didik dan pendidik dan melengkapi kekurangan buku teks pelajaran yang digunakan sebagai bahan ajar, serta sesuai dengan lingkungan pembelajaran. Alasan lain, peneliti mengembangkan LKPD teks cerita fabel karena kemampuan belajar setiap peserta didik berbeda maka dengan bantuan LKPD, diharapkan dapat membantu peserta didik untuk belajar menulis teks cerita fabel secara mandiri. Selain itu, pengembangan LKPD ini juga untuk menambah sumber bahan ajar tentang teks cerita fabel.

Penelitian pengembangan LKPD teks cerita fabel untuk kelas VIII ini juga belum pernah dilakukan. Beberapa penelitan serupa juga pernah dilakukan oleh beberapa orang, yaitu Puspitoningrum (2010) melakukan penelitian "Pengembangan Bahan Ajar Menulis Dongeng Menggunakan Pendekatan Kontekstual untuk Siswa SMP Kelas VII" dengan hasil penelitian yang menunjukkan bahwa dari hasil uji bahan ajar dengan ahli sastra menghasilkan rata-rata kelayakan sebesar $68,18 \%$, ahli pembelajaran $82,35 \%$, guru Bahasa Indonesia 91,17\%, dan siswa 88,12\%. Hasil uji dengan ahli sastra menunjukkan bahan ajar tergolong cukup layak. Kemudian, penelitian yang dilakukan oleh Yusuf (2013) tentang "Pengembangan Lembar Kerja Siswa (LKS) Pelajaran Bahasa Indonesia Kelas VII SMP" dengan hasil penelitian yang menunjukkan bahwa LKS yang dikembangkan dikategorikan baik dan dapat meningkatkan nilai siswa. Penelitian relevan berikutnya oleh Purwati (2013) yang melakukan penelitian tentang "Pengembangan Model Intergratif Berbasis Aspek Wacana pada Pembelajaran Menulis Dongeng Peserta Didik SMP" dengan hasil penelitian ini menunjukkan bahwa model integratif berbasis aspek wacana meningkatkan nilai ketuntasan peserta didik dan memengaruhi perubahan sikap kreatif dan mandiri peserta didik. Dari beberapa penelitian relevan tersebut menunjukkan bahwa belum ditelitinya pengembangan Lembar Kerja Peserta Didik (LKPD) pada materi teks fabel dengan pendekatan saintifik untuk siswa SMP Kelas VIII.

Berdasarkan uraian tersebut, maka rumusan masalah dalam penelitian ini adalah (a) Bagaimanakah kebutuhan peserta didik dan guru dalam pembelajaran menulis teks cerita fabel?, (b) Bagaimanakah hasil LKPD Teks Cerita Fabel berbasis saintifik yang dikembangkan?, dan (c) Bagaimanakah hasil validasi LKPD Teks Cerita Fabel yang dikembangkan? Kemudian, tujuan penelitian ini adalah 
mendeskripsikan kebutuhan peserta didik dan guru; menghasilkan LKPD Teks Cerita Fabel berbasis saintifik; dan mendeskripsikan hasil validasi LKPD Teks Cerita Fabel berbasis saintifik.

\section{METODE}

Metode penelitian menggunakan metode penelitian pengembangan (research and develompment). Penelitian pengembangan ini mengadaptasi model pengembangan Jolly dan Bolitho yang dimodifikasi dengan model pengembangan Dick, Carey, dan Carey. Adapun rincian langkah-langkah pengembangan LKPD Teks Cerita Fabel menggunakan modifikasi model Jolly dan Bolitho (dalam Tomlinson, 1998:98) dan model Dick, Carey, \& Carey (2005:6-7), meliputi: 1) identifikasi kebutuhan guru dan siswa; 2) eksplorasi kebutuhan materi yang berkaitan dengan keterampilan menulis yang mengacu pada $\mathrm{KI}$ dan $\mathrm{KD}$; 3) realisasi kontekstual, dengan melakukan analisis karakteristik materi dan pembelajaran, serta sumber belajar; 4) realisasi pedagogik dengan menentukan strategi pengorganisasian pembelajaran, penyampaian isi, pengelolaan pembelajaran, dan pengelolaan pembelajaran; 5) produksi LKPD; 6) Validasi LKPD oleh ahli; 7) revisi LKPD setelah validasi; 8) Penggunaan LKPD.

Subjek penelitian ini adalah peserta didik dan guru bahasa Indonesia SMP kelas VIII. Teknik pengumpulan data yang digunakan dalam penelitian ini adalah kuesioner (angket). Kuesioner dalam penelitian ini diberikan kepada peserta didik, guru, dan pakar/ahli. Kuesioner peserta didik dan guru digunakan untuk memperoleh informasi tentang kebutuhan dan harapan mereka terhadap bahan ajar teks cerita fabel. Kuesioner pakar/ahli digunakan untuk mendapatkan informasi mengenai kualitas produk bahan ajar yang dikembangkan, yaitu menulis teks cerita fabel. Kuesioner yang diberikan kepada pakar/ahli dibuat berdasarkan pada tiga komponen penilaian bahan ajar, yaitu (1) komponen kelayakan isi, (2) komponen kebahasaan, (3) komponen penyajian dan kegrafikaan. Untuk memberikan makna dan mengambil keputusan berdasarkan nilai yang diberikan oleh pakar/ahli tentang kelayakan bahan ajar yang dikembangkan digunakan kriteria kelayakan bahan ajar. Skor yang diperoleh dari masing-masing kriteria penilaian komponen bahan ajar kemudian dijumlahkan. Perolehan skor yang telah dijumlahkan kemudian dikategorikan berdasarkan kriteria berikut.

Tabel 1. Kriteria Kelayakan Bahan Ajar

\begin{tabular}{cc}
\hline Nilai & Kriteria \\
\hline $86-100$ & Sangat Layak \\
\hline $71-85$ & Layak \\
\hline $56-70$ & Cukup Layak \\
\hline $41-55$ & Kurang Layak \\
\hline$\leq 40$ & Tidak layak \\
\hline Diadaptasi dari & Kriteria Penilaian (Riduwan, 2009:49)
\end{tabular}

Data yang diperoleh dari angket kebutuhan bahan ajar yang diberikan kepada peserta didik dan pendidik diolah dan dianalisis secara objektif kemudian dideskripsikan. Adapun langkah-langkah analisis kuesioner kebutuhan peserta didik dan pendidik, yaitu sebagai berikut: (1) data angket diperiksa dan diklasifikasikan secara objektif; (2) data angket dianalisis dan dideskripsikan; dan (3) data angket disimpulkan. Data dari kuesioner penilaian oleh pakar/ahli dianalisis secara deskriptif. Analisis dilakukan dengan melakukan penyekoran terhadap setiap 
alternatif jawaban yang dipilih pakar/ahli, kemudian dideskripsikan serta ditarik kesimpulan. Pemberian makna dan pengambilan keputusan berdasarkan nilai yang diberikan oleh pakar/ahli didasarkan pada kriteria penilaian kuesioner pakar/ahli. Masing-masing hasil penilaian komponen bahan ajar, kemudian diberi skor berdasarkan kriteria penilaian yang telah dibuat.

\section{HASIL}

Berdasarkan identifikasi kebutuhan pada peserta didik diketahui bahwa fakta yang ada buku teks yang digunakan sebelumnya masih memiliki keterbatasan dalam beberapa aspek. Pada aspek isi ada beberapa kekurangan/keterbatasan, yaitu (a) materi yang disajikan dalam buku teks menurut peserta didik masih kurang lengkap; (b) materi dan contoh yang diberikan kurang banyak dan sulit dipahami. Lalu, pada aspek desain tampilan ada beberapa keterbatasan, yaitu (a) warna kurang menarik, (b) ukuran font kurang besar, dan (c) gambar ilustrasi kurang banyak dan menarik. Kemudian, pada aspek bahasa juga ada beberapa kekurangan, yaitu bahasa yang digunakan terlalu kompleks dan padat sehingga peserta didik malas membaca dan sulit memahami isi buku teks. Pada kegiatan pembelajaran, saat diminta menulis teks cerita fabel, peserta didik juga mengalami kesulitan untuk memulai menulis teks.

Sama halnya dengan peserta didik, menurut guru bahasa Indonesia, buku teks yang digunakan sebelumnya masih memiliki beberapa kekurangan. Menurut guru bahasa Indonesia, kekurangan/keterbatasan buku teks pada aspek isi adalah materi tentang unsur kebahasaan masih perlu ditambah, kemudian contoh-contoh yang diberikan kurang banyak dan kurang sederhana sehingga sulit dipahami peserta didik. Sedangkan, pada aspek desain tampilan sudah cukup menarik. Pada aspek bahasa sudah cukup jelas, hanya ada beberapa kosakata yang belum dimengerti oleh peserta didik.

Adapun harapan peserta didik dan guru terhadap bahan ajar yang akan dikembangkan adalah bahan ajar yang (a) menyajikan materi yang lengkap, terutama tentang unsur kebahasaan, dan struktur teks; (b) memberikan banyak contoh yang sederhana; (c) dilengkapi dengan latihan/tugas yang mudah dipahami dan bersifat produktif, (d) rubrik penilaian untuk setiap tugas, (e) desain tampilan yang menarik, dengan warna-warna dan gambar-gambar yang dapat menstimulus peserta didik untuk minat membaca bahan ajar, serta penggunaan ukuran huruf yang sedang, dan (f) penggunaan bahasa yang sederhana, komunikatif, jelas, efektif, dan efisien.

Dari hasil identifikasi kebutuhan yang diperoleh maka dikembangkan bahan ajar yang sesuai dengan harapan peserta didik dan guru bahasa Indonesia, peneliti merancang dan mengembangkan LKPD pada materi teks cerita fable berbasis saintifik. LKPD Teks Cerita Fabel yang dikembangkan, terdiri dari tiga (3) bagian utama, yaitu (a) bagian pendahuluan, meliputi sampul depan (cover), kata pengantar, dan daftar isi; (b) bagian isi, meliputi KD, tujuan pembelajaran, dan indikator, kegiatan pembelajaran, uraian materi, latihan dan tugas, glosarium, dan rubrik penilaian; (c) bagian penutup, meliputi daftar pustaka, biodata penulis, dan sampul belakang (cover). Berdasarkan hasil identifikasi kebutuhan terhadap peserta didik dan guru, serta ekplorasi kebutuhan materi, realisasi kontekstual dan realisasi pedagogik, berikut merupakan spesifikasi bahan ajar LKPD Teks cerita fabel yang akan dikembangkan. 
LKPD yang akan dikembangkan terdiri dari tiga (3) bagian, yaitu bagian pendahuluan, bagian isi, dan bagian akhir. Berikut ini merupakan rancangan LKPD teks cerita fabel berbasis saintifik yang dikembangkan.

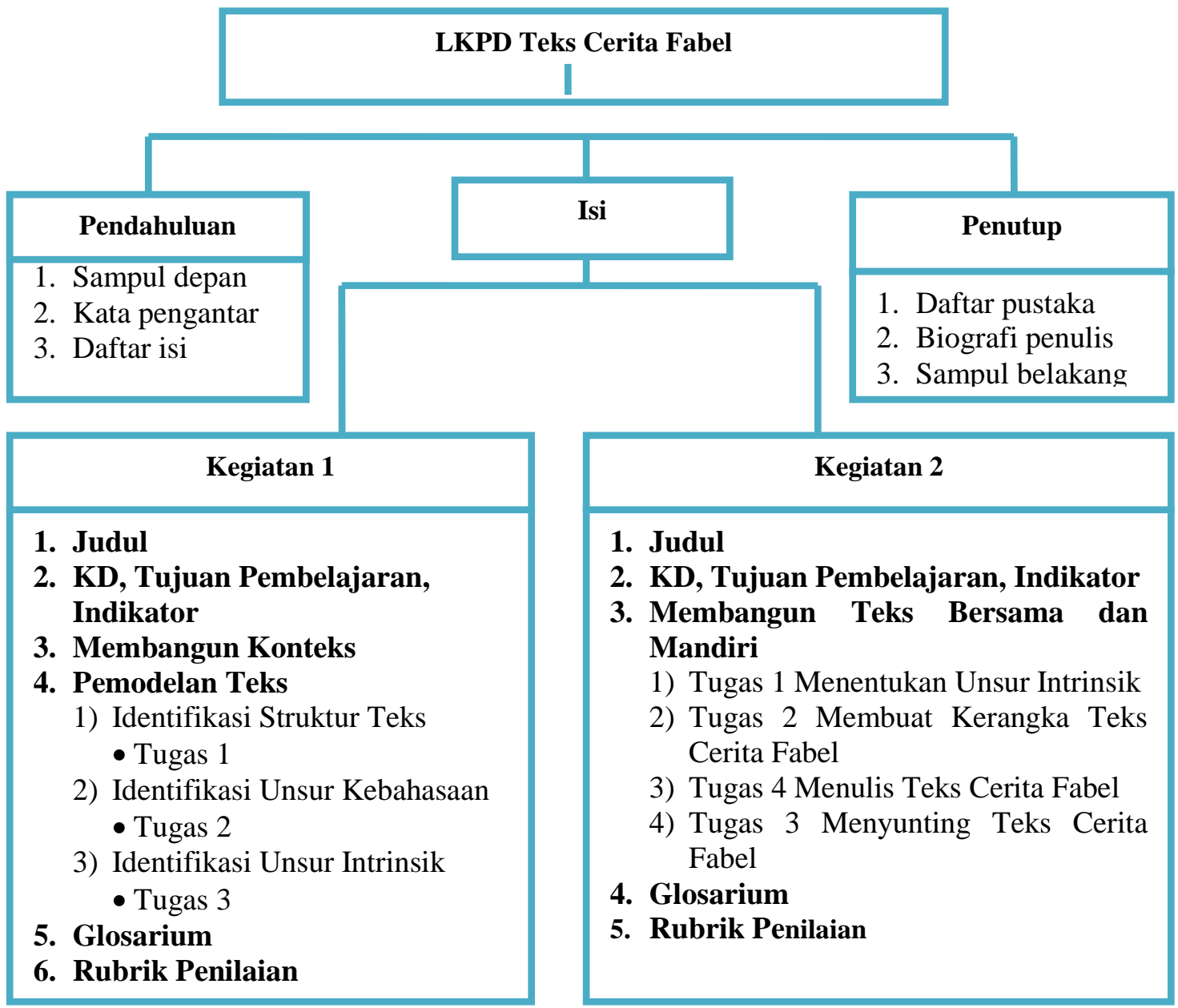

\section{Gambar 1. Rancangan LKPD Teks Cerita Fabel Berbasis Saintifik}

Rancangan LKPD Teks Cerita Fabel yang telah dibuat, kemudian direalisasikan dan dikembangkan sesuai dengan spesifikasi LKPD Teks Cerita Fabel dari hasil identifikasi kebutuhan. Setelah penyusunan dan pengembangan LKPD Teks Cerita Fabel berdasarkan rancangan pada Gambar 3, maka langkah selanjutnya adalah melakukan penilaian LKPD oleh para ahli. Validasi ahli dilakukan untuk mengetahui kelayakan LKPD Teks Cerita Fabel sebagai bahan ajar. Aspek LKPD Teks Cerita Fabel yang divalidasi oleh ahli, yaitu: a) isi/materi, b) bahasa, c) sajian dan kegrafikaan. Dari hasil penilaian ahli, aspek isi/materi LKPD Teks Cerita Fabel memperoleh jumlah skor 30. Aspek kebahasaan LKPD Teks Cerita Fabel memperoleh jumlah skor 17. Aspek penyajian dan kegrafikaan LKPD Teks Cerita Fabel memperoleh jumlah skor 42. Total dari jumlah skor yang diperoleh pada aspek isi/materi, kebahasaan, penyajian dan kegrafikaan adalah 89. Berdasarkan kriteria kelayakan bahan ajar pada tabel 1 maka LKPD Teks Cerita Fabel sangat layak digunakan sebagai salah satu bahan ajar komplementer oleh peserta didik dan guru Bahasa Indonesia Kelas VIII. 


\section{PEMBAHASAN}

Dalam penyusunan LKPD Menulis Teks Cerita Fabel berbasis saintifik, kegiatan pembelajaran terdiri dari dua kegiatan, yaitu (a) memahami teks fabel dan (b) menulis teks cerita fabel. Setiap kegiatan pembelajaran tersebut disesuaikan dengan pendekatan saintifik, yaitu diawali dengan kegiatan mengamati, menanya, mengumpulkan informasi, mencoba, dan mengkomunikasikan, serta pembelajaran bahasa berbasis teks, yaitu membangun konteks, membangun teks secara bersama, dan membangun teks secara mandiri.

Pada kegiatan 1, yaitu memahami teks cerita fabel, peserta didik secara bersama-sama membangun konteks tentang teks cerita fabel, meliputi struktur teks cerita fabel, unsur kebahasaan, dan unsur intrinsik. Penulis menambahkan materi tentang struktur teks, unsur kebahasaan, dan unsur intrinsik berdasarkan kebutuhan peserta didik yang mengalami kesulitan atau kendala yang dialami dalam kegiatan menulis teks cerita fabel. Oleh karena tujuan pengembangan LKPD ini adalah untuk memudahkan peserta didik dalam belajar menulis teks cerita fable. Hal tersebut sesuai dengan fungsi LKPD yang dikemukakan oleh Prastowo (2011:207), yaitu LKPD berfungsi sebagai bahan ajar yang mempermudah peserta didik untuk memahami materi yang diberikan. Kemudian bahan ajar LKPD yang disusun juga memberikan pengalaman belajar peserta didik yang bersifat kreatif, kolaboratif, kerja sama, dan berpikir kritis (Noermanzah \& Friantary, 2019:6631).

Pada kegiatan 2, yaitu menulis teks cerita fabel, peserta didik secara bersamasama dan secara individu membangun teks cerita fabel. Kegiatan pembelajaran menggunakan pendekatan saintifik, melalui tahapan pramenulis, menulis, dan pascamenulis. Penyusunan tahapan kegiatan pembelajaran 2 sesuai dengan pendekatan proses dalam menulis, bertujuan untuk membiasakan peserta didik melakukan kegiatan pramenulis sebelum menulis dan melakukan kegiatan pascamenulis sesudah menulis sehingga memudahkan peserta didik dalam menulis teks cerita fabel. Hal tersebut senada dengan pendapat yang dikemukakan oleh Zainurrahman (2011:10), yaitu pendekatan proses dalam menulis memudahkan penulis pemula untuk memulai kegiatan menulis.

Kegiatan pembelajaran pada LKPD dilengkapi dengan banyak teks cerita fabel untuk dibaca peserta didik pada kegiatan mengamati, menanya, dan mengumpulkan informasi. Selain itu, LKPD juga dilengkapi latihan dan tugas yang bersifat produktif baik secara kelompok ataupun secara individu yang dilakukan pada kegiatan mencoba disertai rubrik penilaian. Penulis juga menambahkan glosarium untuk menambah kosakata peserta didik. Isi LKPD disampaikan secara sederhana, efektif dan efisien sehingga peserta didik dapat memahami isi materi dan petunjuk dalam LKPD yang dikembangkan. Desain tampilan, LKPD Teks Cerita Fabel disajikan dengan warna-warna yang beragam dan gambar-gambar yang menarik sehingga peserta didik berminat dan senang menggunakan LKPD. Kemudian, LKPD juga ditulis menggunakan jenis huruf constantia, lucida calligraphy, dan bookman old style ukuran 12.

LKPD dikembangkan untuk melengkapi kekurangan/keterbatasan bahan ajar yang digunakan sebelumnya. Adapun kelebihan LKPD Teks Cerita Fabel yang dikembangkan, yaitu: (a) LKPD disusun berdasarkan identifikasi kebutuhan peserta didik dan guru, maksudnya isi/materi, latihan/tugas, dan desain tampilan disesuaikan dengan kebutuhan peserta didik dan guru; (b) LKPD disusun berdasarkan pendekatan saintifik. Penggunaan pendekatan saintifik pada pengembangan LKPD 
juga bertujuan untuk meningkatkan hasil belajar yang tinggi, sebagaimana pendapat Lazim (2013:2) yang mengemukakan bahwa pendekatan saintifik bertujuan untuk meningkatkan kemampuan berpikir peserta didik untuk menyelesaikan masalah secara sistematik sehingga memeroleh hasil belajar yang tinggi. LKPD juga menekankan pembelajaran yang bersifat produktif, sehingga pada akhir pembelajaran peserta didik menghasilkan teks cerita fabel.

Berdasarkan hasil validasi yang diberikan oleh para ahli, LKPD Teks Cerita Fabel sangat layak digunakan sebagai bahan ajar komplementer dalam pembelajaran Bahasa Indonesia, khususnya pada materi teks cerita fabel. Selain penilaian pada komponen isi, kebahasaan, dan penyajian, para ahli juga memberikan juga memberikan saran dan komentar, sebagai berikut.

Tabel 2. Saran dan Komentar Pakar dan Hasil Revisi Validasi

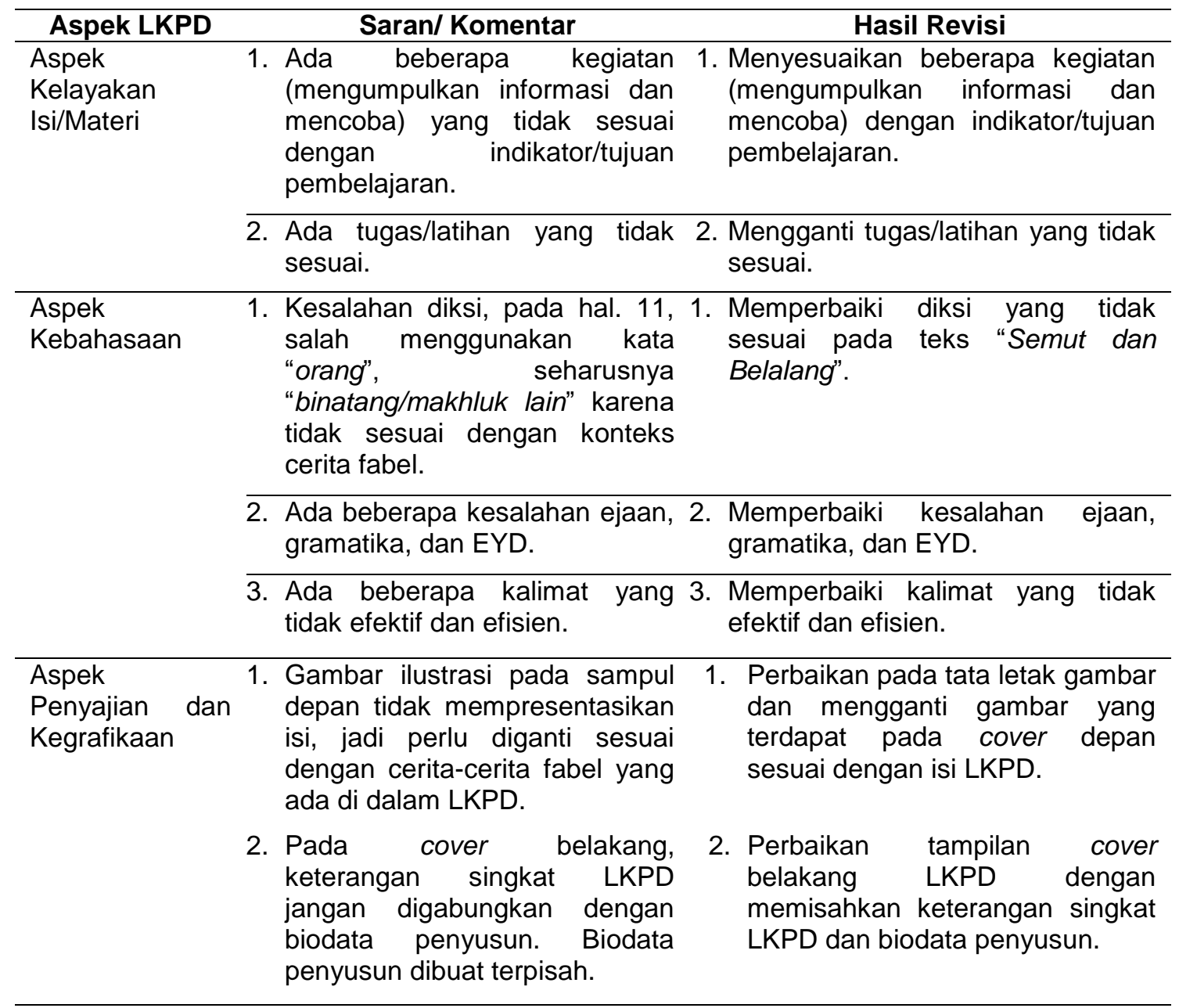

\section{SIMPULAN DAN SARAN}

Berdasarkan hasil identifikasi kebutuhan, peserta didik dan guru membutuhkan bahan ajar yang sesuai dengan kebutuhan mereka sehingga dapat memudahkan mereka dalam pembelajaran menulis teks cerita fabel. Peserta didik dan guru membutuhkan bahan ajar yang (a) dilengkapi dengan materi, contoh, latihan/tugas yang bersifat produktif, dilengkapi dengan rubrik penilaian; (b) 
disampaikan dengan bahasa yang sederhana, komunikatif, efektif, dan efisien; (c) disajikan dengan warna dan gambar yang menarik, serta tulisan yang jelas.

Berdasarkan hasil identifikasi kebutuhan, eksplorasi kebutuhan materi, realisasi kontekstual, dan pedagogik, maka dirancang sebuah bahan ajar, berupa LKPD Teks Cerita Fabel berbasis saintifik. LKPD Teks Cerita Fabel terdiri dari tiga (3) bagian, yaitu bagian pendahuluan, meliputi sampul depan (cover), kata pengantar, dan daftar isi; (b) bagian isi, meliputi KD, tujuan pembelajaran, dan indikator, kegiatan pembelajaran, uraian materi, latihan dan tugas, glosarium, dan rubrik penilaian; (c) bagian penutup, meliputi daftar pustaka, biodata penulis, dan sampul belakang (cover). LKPD Teks Cerita Fabel dikembangkan sesuai dengan pendekatan saintifik, pembelajaran bahasa berbasis teks, dan proses menulis. Berdasarkan hasil validasi oleh para ahli pada aspek isi/materi, kebahasaan, serta penyajian dan kegrafikaan, LKPD Teks Cerita Fabel berbasis saintifik dinyatakan baik atau layak untuk digunakan sebagai salah satu bahan ajar menulis teks cerita fabel untuk digunakan peserta didik.

\section{DAFTAR PUSTAKA}

Dick, W., Carey, L., \& Carey, J. O. (2005). The Systematic Design of Instruction. London: Pearson.

Lazim, M. (2013). "Penerapan Pendekatan Saintifik dalam Pembelajaran Kurikulum 2013".http://www.pppgkes.com/index.php?option=com_phocadownload\&vie $\mathrm{W}=$ category\&download=122:penerapan-pendekatan-saintifik-dalampembelajaran-kurikulum-2013\&id=1:widyaiswara. Diakses pada 1 April 2019.

Marianita, M., \& Artati, A. (2018). Pengaruh Model Pembelajaran Writing in the Here and Now dalam Menulis Bahan Ajar Mahasiswa Program Studi Pendidikan Bahasa Indonesia STKIP PGRI Lubuklinggau. Silampari Bisa: Jurnal Penelitian Pendidikan Bahasa Indonesia, Daerah, dan Asing, 1(1), 175. doi:10.31540/silamparibisa.v1i1.22

Noermanzah \& Friantary, H. (2019). Development of Competency-Based Poetry Learning Materials for Class X High Schools. International Journal of Recent Technology and Engineering, 8 (4), 6631.

Nugroho, A. (2018). Nilai Sosial dan Moralitas dalam Naskah Drama Janji Senja Karya Taofan Nalisaputra. Silampari Bisa: Jurnal Penelitian Pendidikan Bahasa Indonesia, Daerah, dan Asing, 1(2), 28-42. doi:10.31540/silamparibisa.v1i2.153

Nugroho, A., \& Fitri, L. (2018). Respons Siswa SMP Negeri se Kota Lubuklinggau terhadap Bahan Ajar Cerita Rakyat Lubuklingau. Silampari Bisa: Jurnal Penelitian Pendidikan Bahasa Indonesia, Daerah, dan Asing, 1(1), 117. doi:10.31540/silamparibisa.v1i1.11 
Prastowo, A. (2011). Panduan Kreatif Membuat Bahan Ajar Inovatif. Yogyakarta: Diva Press.

Purwati, P. D. 2013. "Pengembangan Model Integratif Berbasis Aspek Wacana pada Pembelajaran Menulis Dongeng Peserta Didik SMP". (Online). http://publikasiilmiah.ums.ac.id/bitstream/handle/123456789/3334/14_Penge mbangan\%20Model\%20Integratif\%20Berbasis\%20Aspek\%20Wacana\%20P ada\%20Pembelajaran\%20Menulis\%20Dongeng\%20Peserta\%20Didik\%20S MP.pdf?sequence=1. Diakses 01 Februari 2019.

Puspitoningrum, E. (2010). "Pengembangan Bahan Ajar Menulis Dongeng Menggunakan Pendekatan Kotenkstual untuk Siswa SMP Kelas VII". http://karya-ilmiah.um.ac.id/index.php/sastra-indonesia/article/view/10353. Diakses 2 Februari 2019.

Riduwan. (2009). Pengantar Statistika Sosial. Bandung: Alfabeta.

Sarumpaet, R. K. T. (2010). Pedoman Penelitian Sastra Anak: Edisi Revisi. Jakarta: Yayasan Pustaka Obor Indonesia.

Suryaman, M. (2012). "Bahan Ajar Bahasa Indonesia RSBI". http://staff.uny.ac.id/sites/default/files/pengabdian/dr-maman-suryamanmpd/bahan-ajar-bi-smk-rsbi-2012-final.pdf. Diakses 1 Mei 2019.

Tomlinson, B. (1998). Materials Development in Language Teaching. London: Cambridge University Press.

Yusuf. (2013). "Pengembangan Lembar Kerja Siswa (LKS) Pembelajaran Bahasa Indonesia Kelas VII SMP". Tesis. Prodi Pendidikan Bahasa: Pascasarjana Universitas Sriwijaya.

Zainurrahman. (2011). Menulis: Dari Teori Hingga Praktik (Penawar Racun Plagiarisme). Bandung: Alfabeta. 